\title{
STUDENTS' AND INSTRUCTORS VOICES OF THE TALKING APPRAISAL IN INDONESIA
}

\author{
Alexander Musa \\ alexandermusa69@gmail.com
}

\begin{abstract}
In school, teachers have tremendous impact in looking into talking limit since the inconceivable effect assessment will be sway on understudies improvement, instructors ought to have the information and appreciation concerning what they asses, how they asses and collect the information of understudies to get the persuading appraisal from students. The analyst will utilize interview to know both viewpoint on students and teacher toward the evaluation of talking and the understudies understanding toward the exercises/task that given by instructors in talking class. Additionally, the analyst will see the class, pushed regarding how the instructors asses students talking limit. What strategy the educator use and concern the assessment educational plan 2013. What's more it in like way concern what sort of endeavored the instructor use in the homeroom to move students talking capacity. Moreover, the analyst will record the advancement related with talking in class. There are some record additionally will be gathered in this appraisal like the material of talking class, and affiliation talking assessment from instructors.

Keywords: Talking appraisal, students' voice, instructors' voice
\end{abstract}

\section{Establishment}

Conveying in is seen by language analyzers as the most tricky of the four language abilities to outline. Investigating talking expects that we either notice a "live" oral execution or that we get the showcase by explicit means for examination soon. A technique for elicitation should be picked, rating scales should be made, and inspectors as well as raters should be prepared (Marzuki, 2016; Fatimah and Santiana, 2017; Alek et al., 2020a; Marzuki and Kuliahana, 2021; Santiana et al., 2021).

In school, instructors have tremendous effect in investigating talking limit since the exceptional effect assessment will be sway on understudies improvement, teacher ought to have the information and insight concerning what they asses, how they asses and collect the information of understudies to get the persuading evaluation from understudy. Regardless, talking evaluation is irksome considering the way that a couple of moments' talking proof isn't acceptable to censure a student's ability (Waugh and Joliffe, 2008). It is endeavoring to outline talking, by goodness of the various elements that influence the way wherein instructors study oral capacity. Parts that are viewed as customarily basic wire pressure, complement, language, goofs and the capacity to utilize language fittingly to speak (Richards, 2008; Bora, 2012; Marzuki, 2017; Thuy and Nga, 2018; Santiana et al., 2021).

There are something like three test that looked by educators in talking assessment, saving several minutes, picking the evaluation exercises and finishing up examination rules. The instructor should anticipate assessment, notice the understudies, and record their show. In the mean time, to finish the improvement in talking, the understudy input in talking assessment is 
likewise required. For the current situation the point of view on understudies toward talking evaluation concerning the assignment of assessment that teacher use is basic. Keenness is the way updates are picked and gathered by a person with the objective that the redesigns can be truly unwound. As proposed by Kleinke (1978), comprehension can influence understudies' accomplishment in learning language. Thusly, there is relationship among discernment and recognizing which occurs among the understudies in talking class. Exactly when the understudies comprehend the things they see focused of teachers' assignment that given by them, and they have positive data they will be truly in talking class. Inaddition the viewpoint on understudies comparably will manage the setback of assignment or advancement from educator. Moreover, teachers know how to manage their picked try or exercises in talking class. Suitably, the talking assessment truly spellbinding to investigate, pushed according to two side viewpoint on educator and understudy.

Looking at talking assessment, it can't be isolates from educational game plan. The most best in class enlightening system that embraced in Indonesia is 2013 educational game plan. Taking into account that standard, in the start of 2013, The Ministry of National Education of Indonesian Government organized another informational game plan for the straightforward until senior assistant schools named as Curriculum 2013. As the certification of the public power, Curriculum 2013 is a change of the past informative game plan, Curriculum 2006 or KTSP. There are two or three materials added to Curriculum 2013 which are not introduced in Curriculum 2006, and besides there are several materials killed from Curriculum 2013 which are introduced in Curriculum 2006. As portrayed in Regulation of Republic Indonesia No. 66 Year 2013 regarding Education Assessment Standards, Curriculum 2013 is utilizing veritable appraisals, self-assessment, portfolio assessment, developmental assessment, and summative assessment.(Natalia:2015)

With a definitive goal of conversation, there are two or three evaluations that had been driven concerning talking assessment. widhiayu (2018) research understudies' understanding on the utilization of video to concentrate on understudies' introductions in Public Speaking class. This study base noticeable of understudies of the utilization video straightforwardly talking. In any case, the concentrate basically spins around the public talking class and the impression of understudies' in the overview, the utilization of teachers' information has not been investigated in the review. Subsequently, it is crucial for research the educators' understanding in the force review, considering the way that the point of view from educator likewise can cause the peruser to comprehend whether or not there is progress when instructor use video.

One more review composed by Thuy (2018), the overview analyzed EFL educators' impression of in-class English talking assessment. The types of educators' pieces of information investigated in the energy research intertwined their overall discernment of talking assessment, the assignment kinds of in-class talking appraisal, and the teachers' business related with the assessment execution. This emphasis on base on the overall comprehension of talking evaluation without including the educational game plan that now use. In like way, in the current review, it is 
principal to investigate the talking assessment with instructor viewpoint and the evaluation related with educational program.

Thus, in the current review, the master will utilize the part from capable school and use keenness from both side educators' and understudies' information. There are some quality of concentration in this appraisal explicitly sort of talking appraisal that utilized by instructor, the teacher impression of talking assessment considering informational program 2013, the understudies point of view on talking assessment pushed of undertaking types that given by educators in talking class. The review will utilized assembling, understanding and documentation as instrument of appraisal.

\section{Methods}

The scientist will utilize interview to know both point of view on understudy and instructor toward the evaluation of talking and the understudies understanding toward the exercises/task that given by teacher in talking class. Likewise, the inspector will see the class, focused concerning how the educator asses understudy talking limit. What system the educator use and concern the assessment enlightening plan 2013. What's more it additionally concern what sort of embraced the instructor use in the homeroom to bring understudy talking capacity. Besides, the analyst will record the advancement related with talking in class. There are some record additionally will be collected in this appraisal like the material of talking class, and affiliation talking assessment from instructor.

\section{Composing Review}

As a significant expertise, talking is wandered randomly among different informed authorities. The strength of talking limits is considered to be a prerequisite for most EFL and ESL students (Richards, 2008, p. 19; Florez, 1999). While endeavoring to depict speaking, Richards (2006) battles for the "customary 'language use" which happens "when a speaker looks into basic alliance and stays mindful of fathomable and propelling correspondence in spite of restrictions in their open capacity" (p. 14). Richards' meaning of talking reverberations the interactional piece of language that is utilized to fuel social intercourse (Yule, 1989, p. 169), to impel capacity to understand people on a more significant level (Bora, 2012), to satisfy express objectives or to pass on unequivocal considerations, suspicions, necessities, propensities, or assessments. Another keenness comes from Thornbury (2005: iv). He portrays talking as an instinctual collaboration which requires the capacity to partake in the association of talking turns. In the interim, Byrne (1997: 8) in Liao (2009) tells that talking or oral correspondence is a twoway process among speakers and group people which fuses the significant limit of talking and open inclination of insight (or tuning in with appreciation).

Along these lines, talking is objective and talking as well as including understanding and several components that influence a solitary's talking limit. As shown by Kingen (2000), talking satisfies the going with twelve cutoff points:

1). Personal - conveying individual conclusions, opinions, convictions and contemplations.

2). Descriptive-depicting a person or thing, guaranteed or envisioned.

3). Narrative - making and recapping stories or progressively sequenced occasions. 
4). Instructive - giving guidelines or giving course intended to convey a result.

5). Questioning - introducing solicitations to obtain data.

6). Comparative - looking at least two articles, individuals, examinations, or closures to make decisions regarding them.

7). Imaginative - conveying mental pictures of individuals, spots, occasions, and articles.

8). Predictive-anticipating conceivable future occasions.

9). Interpretative - investigating ideas, offering speculative permissive signals, and pondering surmisings.

10). Solid - transforming others' perspectives, mentalities, or perspectives, or impacting the direct of others somehow or another.

11). Intelligible - clarifying, explaining, and supporting contemplations and closures.

12). Instructive - offering data to other people.

As per a few specialists' viewpoints about talking and conversational cutoff points, understudies are depended upon to have the decision to utilize a piece of the supporting liabilities of data, authority of language, development of thoughts with the objective that this message can be passed on well by swarm people or perusers. Besides, different scientists have examined characteristics talking as not by and large identical to other tremendous extension English limits. moreover has been clarified over as far as possible. considering the cutoff and talking influence on understudy information, instructor assessment in a general sense impacts the degree of understudy capacity and what the understudies input.

As indicated by Dorobat's clarification (2007: 2), educators' appraisal intimates an assortment of courses in get-together data on student's capacity or accomplishment by considering on viewpoints or pointers that will be observed. This proposes that instructors can apply different procedures to outline understudies' talking limits. To observe their social limits considering their program, teachers should configuration talking evaluation rehearses since it is their obligation to control understudy progress.

There are two or three talking rehearses that can be utilized. As per Brown (2004), there are two or three major kinds of talking and its procedure of assessment. They are as per the going with:

\section{Imitative}

It is the capacity to mirror a word, verbalization, or a sentence. In this sort, the edifying limit of the language isn't key so that test takers don't have to handle or give meaning or to take part in a clever discussion. It deduces that the understudies base on articulation despite the way that complement comparatively shares as the scoring standards. There are two or three exercises that ought to be attainable to evaluate understudies' talking limit thinking about this imitative sort. They are word obvious redundancy task, telephone finish assessment, emphasize sentences.

\section{Intensive}

This kind of talking doesn't feature on manner of speaking. It more spotlight on the importance than the react of the essential speaker. To have the decision to react well the understudies need to grasp the importance even they have immaterial cooperation with the 
educators or their friens as the conversationalists in the discussion. Events of increased assessment attempts join worked with reaction assignments, looking at resoundingly, sentence and exchange finishing, Limited picture-hailed errands. While O'Malley (1996: 79) conveyed that image hailed portrayals or stories appraisal methodology can be utilized for individual and starting or focus understudy. The instructor should configuration gathering of high distinction or hidden pictures or photo. The photos ought to be proper for age level of the understudies.

3. Responsive

Responsive appraisal tries consolidate the relationship of fundamental two novel ways correspondence and test understanding like staggeringly short discussions, standard incredible news and loosened up conversation, clear demands and remarks, and so on Since the realness of discussion is basic, in this way the test takers should talk or react instantly. There are some assessment procedures that ought to be plausible to outline understudies' talking limit thinking about this responsive kind. They are $\mathrm{Q}$ and $\mathrm{A}$, provide guidance and course, summarizing, Test of Spoken English (TSE).

4. Interactive

In intuitive talking, the complex plan of affiliation can be happened. It is considering the way that the relationship in talking has purposes to trade data and keep social affiliations, subsequently there should be different people attracted with the discussion. Some appraisal strategies thinking about this insightful sort are as per the going with; first assignment is interview, O'malley (1996: 78) recognized that oral social event can be composed for all degree of language students by individual understudy or two by two. Second undertaking is envision. Third are conversations and discussions. Fourth are games. Fifth is oral limit interview (OPI).

5. Extensive (talk)

One might say that in this sort of talking has a bound lift from the group people. Extensive oral creation assignments join talks, oral introductions, and depicting. Customarily, the language utilized is in genuine style, it likewise coordinated well going before playing out the wide talking.

O'Malley (1996: 61) imparted that appraisal of oral language should zero in on an understudy's capacity to decipher and convey significance for valid purposes in shrewd setting. It should meld both shared characteristic and accuracy. To make a talking appraisal, the instructors should focus in on the objectives and goals of study hall heading prior to including informative exercises for the assessment. They also need to weight on the capacity level of the understudies. Hence, the teachers need to contemplate the motivation driving the appraisal movement, the average show and the models of each undertaking. Then, at that point, they should plan a scoring rubric, rating scale, or plan considering the activity levels of execution (O'Malley: 1996, p.65). For model rubric or scale, it will combine open impact or general fathomability, language development, and verbalization.

In scoring rubric, the educators should put appraises how the understudies can treat light of their degree of capacity. Straightforwardly following organizing a scoring rubric, rating scale or plan, they need to set norms of oral language execution. To set them, they ought to close the 
show up at score and the depiction extents of execution thinking about each degree of capacity on scoring rubric. Then, at that point, the standards ought to be fitting to the language learning protests in each degree of capacity. The understudies' showcase in like way can be a screen of understudies' movement in showing learning affiliation and determinations of understudies' position.

O'malley (1996: 66-67) clarified that there are two kinds of scoring rubrics for talking appraisal. Those are broad and consistent scales. Expecting the educators utilize a total scale, they just need three to six degrees of execution. Then, at that point, they need to make the rating that fits to the understudies' authentic showcase anxiously considering the way that several understudies might be not fit continually with some class. Expecting the teachers utilize a fast scale to survey understudies' talking execution, they need to focus in on understudies' mettle and necessities.

\section{REFERENCES}

Albana, H. H., Marzuki, A. G., Alek, A., \& Hidayat, D. N. (2020). Cohesive Devices in Student's Writing (A Discourse Analysis on Argumentative Text). Jurnal Pendidikan Humaniora, 8(1), 6-11.

Alek, A., Marzuki, A. G., Farkhan, M., \& Deni, R. (2020). Self-Assessment in Exploring EFL Students' Speaking Skill. Al-Ta lim Journal, 27(2), 208-214.

Alek, A., Marzuki, A. G., Farkhan, M., Surahman, D., Daryanto, D., \& Febrianto, S. (2020). Computer Based Testing in Senior High School on National Examination. Indonesian Journal of Learning Education and Counseling, 2(2), 204-210.

Ary, D. Jacobs, Sorensen \& Razaviceh, A. (2010). Introduction to Research Education., US : Thomson Wadsworth inc.

Bora, F, D. (2012). The impact of emotional intelligence on developing speaking skills: From brain-based perspective. Procedia-Social and Behavioural Sciences, 46, 2094-2098. https://doi.org/10.1016/j.sbspro.2012.05.434

Brown, H.D. (2004). Language Assessment: Principles and Classroom Practices. Longman.

Cahyadi, A. (2020). COVID-19 Outbreak and New Normal Teaching in Higher Education: Empirical Resolve from Islamic Universities in Indonesia. Dinamika Ilmu, 20(2), 255-266.

Cirocki, A., \& Farrell, T. S. (2019). Professional development of secondary school EFL teachers: Voices from Indonesia. System, 85, 102111.

Dorobat, Dumitru. (2007). The Methodology of Evaluation and Testing. Ministerul Educaţiei şi Cercetării Proiectul pentru Învăţământul Rural.

Fatimah, A. S., \& Santiana, S. (2017). Teaching in $21^{\text {st }}$ century: Students-teachers' perceptions of technology use in the classroom. Script Journal: Journal of Linguistic and English Teaching, 2(2), 125. 
Fatimah, A. S., Santiana, S., \& Saputra, Y. (2019). Digital Comic: An Innovation of Using Toondoo as Media Technology for Teaching English Short Story. English Review: Journal of English Education, 7(2), 101-108.

Ghinter,A.Assessment of Speaking,(2013), Acessed on https:// www.researchgate.net / publication/277707664. Retrieved : May $5^{\text {th }}, 2019$

Julia, J., Hakim, A., \& Fadlilah, A. (2019). Shifting Primary School Teachers' Understanding of Songs Teaching Methods: An Action Research Study in Indonesia. International Journal of Education and Practice, 7(3), 158-167.

Kingen, S. (2000). Teaching Language Arts in Middle Schools.: Connecting and Communicating. New Jersey: Lawrence Erlbaum Associates, Publishers.

Kuliahana, A., \& Marzuki, A. G. (2020). Repetition Technique in an EFL Speaking Class in Islamic Higher Education in Indonesia. Academic Journal Perspective: Education, Language, and Literature, 8(1), 20-28.

Marzuki, A. G. (2019). The Roles of School Principal Leadership in Developing English Teachers' Creativities in Palu. Al-Ta lim Journal, 26(3), 267-279.

Marzuki, A. G., \& Kuliahana, A. (2021). Using Language Games to Enhance EFL Students' Speaking Skill in Indonesia. Al-Ta lim Journal, 28(3), 213-222.

Marzuki, A. G., Alim, N., \& Wekke, I. S. (2018). Improving the reading comprehension through cognitive reading strategies in language class of coastal area in indonesia. In IOP Conference Series: Earth and Environmental Science, 156(1), 012050). IOP Publishing.

Marzuki, A.G. (2016). Utilizing cooperative learning in islamic college students' classroom, IJEE (Indonesian Journal of English Education), 3(2), 123-139.

Marzuki, A.G. (2017). Developing speaking skill through oral report in an efl class in indonesia, Al-Ta'lim Journal, 24(3), 243-254.

Muazza, M., Mukminin, A., Habibi, A., Hidayat, M., \& Abidin, A. (2018). Education in Indonesian islamic boarding schools: Voices on curriculum and radicalism, teacher, and facilities. Islamic Quarterly, 62(4), 507-536.

Mukminin, A., Eddy, H., Makmur, M., Failasofah, F., Fajaryani, N., \& Thabran, Y. (2013). The achievement ideology and top-down national standardized exam policy in Indonesia: Voices from local English teachers. Turkish Online Journal of Qualitative Inquiry, 4(4), 19-38.

Natatlia, D .K, (2015). Assessment Techniques Used in the English Classes Based on Curriculum 2013. VNU Journal of Foreign Studies. 34(2).

Richards, J. C. (2006). Communicative Language Teaching Today. New York: Cambridge University Press.

Richards, J. C. (2008). Teaching listening and speaking: From theory to practice. Cambridge: Cambridge University Press.

Safriyani, R., \& Khasanah, S. U. (2021). The strengths and pitfalls of Edmodo to Indonesian EFL learners: Student and teachers' voices. Englisia: Journal of Language, Education, and Humanities, 8(2), 106-119. 
Santiana, S., Lesmana, D. S., Marzuki, A. G., \& Erizar, E. (2021, December). An Insight of Anitales Apps Perceived by Digital Storytelling Students. In Proceeding of International Conference on Islamic Education (ICIED) (Vol. 6, No. 1, pp. 23-30).

Santiana, S., Silvani, D., \& Ruslan. (2021). Optimizing LMS CANVAS for Interactive Online Learning Perceived by the Students. Journal of English Education and Teaching (JEET), 5(4), 529-543.

Santiana, S., Pujasari, R. S., \& Fatimah, A.S. (2021). Blended Learning Strategy: Alternatif Pembelajaran Toefl Bagi Guru-Guru MGMP Non-Bahasa Inggris. Jurnal Inovasi, 1(2020), 144-161. https://ejournal.unib.ac.id/index.php/jurnalinovasi/article/view/15883.

Sugianto, A., \& Ulfah, N. (2020). Construing the challenges and opportunities of intercultural language teaching amid Covid-19 pandemic: English teachers' voices. Journal of English Language Teaching and Linguistics, 5(3), 363-381.

Thornbury, S. (2005). How to Teach Speaking. England: Pearson Education Limited Longman.

Thuy, N, H \& Nga, T, T. (2018). An investigation into Efl Speaking Class Assessment. Accessed on : Wahyuni, S. (2012). Qualitive Research Method: Theory and Practice. Jakarta: Salemba empat

Waugh, D., \& Jolliffe, W. (2008). English 3 - 11: A guide for teachers. Routledge: New York

Whidiayu, S. (2018). Students' Perception on the Use of Video to Assess Performances in Public Speaking Class.

Widodo, H. P. (2017). Constructing and Negotiating Agency and Identity of English Language Learners: Teacher-Learner Driven ESP Materials Development in the Indonesian Secondary School Context. Electronic Journal of Foreign Language Teaching, 14(2).

Yule, G. (1998). The Spoken Language. Annual Review of Applied Linguistics, 10(2), 163-173. 